\title{
Nanoscale
}

CORRECTION

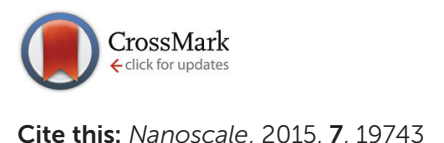

Cite this: Nanoscale, 2015, 7, 19743

\section{Correction: Nitrogen-fluorine co-doped titania inverse opals for enhanced solar light driven photocatalysis}

\author{
T. K. Rahul and N. Sandhyarani* \\ Correction for 'Nitrogen-fluorine co-doped titania inverse opals for enhanced solar light driven photo- \\ catalysis' by T. K. Rahul et al., Nanoscale, 2015, 7, 18259-18270.
}

DOI: $10.1039 / \mathrm{c} 5 \mathrm{nr} 90205 \mathrm{c}$

www.rsc.org/nanoscale
View Article Online

View Journal | View Issue

$$
\eta=\left[\left(A_{0}-A_{t}\right) / A_{0}\right] \times 100 \%
$$

The Royal Society of Chemistry apologises for these errors and any consequent inconvenience to authors and readers. 